\title{
Effect of pasteurization on the decay of Mycobacterium bovis in milk cream
}

\author{
Efeito da pasteurização no decaimento de Mycobacterium bovis \\ em creme de leite
}

\author{
Livia de Andrade Rodrigues ${ }^{1}$; Karina Ramirez Starikoff ${ }^{1}$; Gisele Oliveira de \\ Souza $^{1}$; José Soares Ferreira Neto ${ }^{2}$; Fernando Ferreira ${ }^{2}$; Marcos Amaku²; Ricardo \\ Augusto Dias²; José Henrique Hildebrand Grisi-Filho²; Vítor Salvador Picão \\ Gonçalves ${ }^{3}$; Adriana Cortez ${ }^{4}$; Marcos Bryan Heinemann²; Evelise Oliveira Telles ${ }^{2 *}$
}

\begin{abstract}
Milk cream must be pasteurized in order to be sold in Brazil. However, there are no specific legal requirements for this product, and producers set their own pasteurization parameters using the ones approved for milk as a reference. Considering that fat protects bacteria from heat, that no thermal inactivation studies have been performed on Mycobacterium bovis present in cream, and that bovine tuberculosis is endemic in Brazil, the aim of this study was to evaluate the inactivation of M. bovis in milk cream subjected to commercial parameters of pasteurization. Milk cream samples were contaminated and pasteurized in a water bath at $75,80,85$, and $90^{\circ} \mathrm{C}$ for 5 and $15 \mathrm{~s}$. M. bovis cells were plated onto Stonebrink-Leslie medium, incubated at $36^{\circ} \mathrm{C}$ for 45 days, and quantified; the result was expressed in $\log$ CFU mL $\mathrm{m}^{-1}$. The fat content of the samples ranged from $34 \%$ to $37 \%$ and the average initial load of M. bovis was $8.0 \mathrm{Log} C \mathrm{CFU} \mathrm{mL} \mathrm{mL}^{-1}$. The average decay of the $M$. bovis populations was 4.0, 4.3, 4.9 and $6.7 \log \mathrm{CFU} \mathrm{mL} \mathrm{mL}^{-1}$ when the cream was treated for $15 \mathrm{sec}$ at $75,80,85$ and $90^{\circ} \mathrm{C}$, respectively, showing that the efficiency of the heat treatment was improved by increasing the temperature of the process. Given the lipophilic nature of $M$. bovis, the cream should be subjected to more intense parameters of pasteurization than those applied to milk.
\end{abstract}

Key words: Fat. Mycobacteria. Thermal death. Thermal treatment.

\section{Resumo}

\begin{abstract}
A pasteurização do creme de leite é obrigatória no Brasil, mas não há parâmetros legais específicos para esse produto, de forma que as empresas estabelecem seus próprios parâmetros tendo como referência mínima os aprovados para a pasteurização do leite. Assim, considerando que a gordura tem efeito termo protetor para as bactérias, que não há estudos de inativação térmica do Mycobacterium bovis em creme de leite e que a tuberculose bovina é endêmica no Brasil, o objetivo deste estudo foi avaliar a inativação de $M$. bovis em creme de leite, submetido aos parâmetros comerciais de pasteurização. Amostras de creme de leite foram contaminadas e pasteurizadas em Banho-Maria a $75^{\circ} \mathrm{C}, 80^{\circ} \mathrm{C}, 85^{\circ} \mathrm{C}$ e $90^{\circ} \mathrm{C}$, por
\end{abstract}

1 Discentes, Faculdade de Medicina Veterinária e Zootecnia, Universidade de São Paulo, USP, São Paulo, SP, Brasil. E-mail: laviemacaron@yahoo.com.br; kastarikoff@yahoo.com.br; ginutri@usp.br

2 Profs., Faculdade de Medicina Veterinária e Zootecnia, Universidade de São Paulo, USP, São Paulo, SP, Brasil. E-mail: jsoares@ vps.fmvz.usp.br; fernando@vps.fmvz.usp.br; amaku@vps.fmvz.usp.br; dias@vps.fmvz.usp.br; grisi@vps.fmvz.usp.br; marcosbryan@usp.br; bufalo@usp.br

3 Prof., Faculdade de Agronomia e Medicina Veterinária, Universidade de Brasília, UnB, Brasília, DF, Brasil. E-mail: vitorspg@ unb.br

${ }^{4}$ Prof ${ }^{a}$, Curso de Medicina Veterinária, Universidade de Santo Amaro, UNISA, São Paulo, SP, Brasil. E-mail: acortez@unisa.br

* Author for correspondence

Received: Sept. 27, 2016 - Approved: Sept. 27, 2016 
até $15 \mathrm{~s}$. O M. bovis foi quantificado por semeadura em meio Stonebrink-Leslie, incubado a $36^{\circ} \mathrm{C}$ por 45 dias, e o resultado expresso em $\log \mathrm{UFC} \mathrm{mL} \mathrm{mL}^{-1}$. O teor de gordura das amostras variou de 34 a $37 \%$ e a carga inicial média de $M$. bovis foi de $8,0 \mathrm{Log} \mathrm{UFC} \mathrm{mL}^{-1}$. O decaimento médio da população de $M$. bovis foi de 4,0, 4,3, 4,9 e 6,7 $\mathrm{Log} \mathrm{UFC} \mathrm{mL}^{-1}$, quando expostos respectivamente às temperaturas estudadas por $15 \mathrm{~s}$, demonstrando que a eficácia do tratamento térmico melhorou com o aumento da temperatura do processo. Devido ao caráter lipofílico do M. bovis, o creme de leite deveria ser submetido a parâmetros de pasteurização mais intensos do que aqueles aplicados ao leite.

Palavras-chave: Gordura. Morte térmica. Micobacteria. Tratamento térmico.

\section{Introduction}

Milk cream is a dairy product in the form of a fat emulsion in water and can be classified as lowfat (fat content of 10.0\%-19.9\%), medium-fat (fat content of 20.0-49.9\%), and high-fat (fat content > 50\%) (BRASIL, 1996).

The Brazilian law imposes the pasteurization of milk cream before marketing; however, it does not define specific treatment parameters (BRASIL, 1996); therefore, dairy product companies are free to establish their thermal processing procedures. Some temperature/time treatment combinations employed by Brazilian companies are, for example: $65^{\circ} \mathrm{C}$ for $30 \mathrm{~min}, 75^{\circ} \mathrm{C}$ for $15 \mathrm{~s}, 80^{\circ} \mathrm{C}$ for $15 \mathrm{~s}$, and $85^{\circ} \mathrm{C}$ for 3 to $5 \mathrm{~s}$ (personal communication) $)^{5}$.

Considering the protective effect of fat on various microorganisms (MOLIN; SNYGG, 1967; DONNELLY, 1986; FRANCO, LANDGRAF; 1996; MACDONALD; SUTHERLAND, 1993; CHABRA, 1999; BUSSATA, 2005). Ordóñes Pereda et al. (2005) recommended the use of rapid pasteurization $\left(72^{\circ} \mathrm{C}\right.$ for $\left.15 \mathrm{~s}\right)$ for low-fat milk cream and high-temperature treatments for the other two classes $\left(85\right.$ to $100^{\circ} \mathrm{C}$ for 10 to $15 \mathrm{~s}$ ).

Mycobacterium bovis causes bovine tuberculosis and is one of the non-spore-forming bacteria most resistant to heat. Despite its transmission in milk and its lipophilic nature (SINHA, 1994), no previous studies have assessed the thermal resistance of this pathogen in milk cream. The objective of this study is to evaluate the decay of Mycobacterium bovis in milk cream subjected to different thermal treatments

Information obtained by e-mail from sac@bertin.com.br; piva@balkis.com.br; 1fazenda@leitefazenda.com.br because bovine tuberculosis is endemic in the country and recent studies carried out in 13 States showed prevalence of tuberculosis infected herds among $0.36 \%$ in the Federal District, and $9.0 \%$, in São Paulo (BAHIENSE et al., 2016; BARBIERI et al., 2016; DIAS et al., 2016; GALVIS et al., 2016; GUEDES et al., 2016; LIMA et al., 2016; NÉSPOLI et al., 2016; QUEIROZ et al., 2016; RIBEIRO et al., 2016b; ROCHA et al., 2016; SILVA et al., 2016; VELOSO et al., 2016; VENDRAME et al., 2016).

\section{Materials and Methods}

An isolate of $M$. bovis (spoligotype SB1141) was obtained from a bovine slaughterhouse in the state of São Paulo (RODRIGUEZ at al., 2004). The isolate was grown at $36^{\circ} \mathrm{C}$ for 10 days in StonebrinkLeslie medium (CENTRO PANAMERICANO DE ZOONOSIS, 1985). The inoculum (with a total volume of $12 \mathrm{~mL}$ ) was prepared suspending $0.3 \mathrm{~g}$ of the culture in $0.85 \%$ saline solution with $0.05 \%$ Tween $80 ; 6 \mathrm{~mL}$ of this inoculum were used to infect $100 \mathrm{~mL}$ of commercial pasteurized milk cream previously incubated at $90^{\circ} \mathrm{C}$ for $15 \mathrm{~min}$ in a water bath (WB) to inactivate contaminants, and an aliquot $(5 \mathrm{~mL})$ was taken to determine the initial load (IL). Before the contamination, milk cream was analyzed for fat content using the Gerber method (BRASIL, 2006).

The contaminated milk cream was distributed (5 $\mathrm{mL})$ into three test tubes $(16 \times 160 \mathrm{~mm})$ for each heat treatment investigated. To heat the samples we used a $\mathrm{WB}$ at $95^{\circ} \mathrm{C}$ until the target temperatures $\left(75^{\circ} \mathrm{C}, 80^{\circ} \mathrm{C}, 85^{\circ} \mathrm{C}\right.$, and $\left.90^{\circ} \mathrm{C}\right)$ were reached. One 
of the test tubes was collected for quantitation of the bacterial load (time 0), and the other two test tubes were incubated at each temperature for 5 and $15 \mathrm{~s}$. Five repetitions of the test were performed at each temperature. The temperature of cream was monitored using a mercury thermometer in another test tube containing $5 \mathrm{~mL}$ of not contaminated sample.

The heating curve of the milk cream was determined separately, and the length of the heating process was recorded seven times at all temperatures tested.

Subsequently, samples were subjected to decimal and serial dilutions in $0.1 \%$ peptone water with $0.05 \%$ Tween 80 and plated in duplicate onto StonebrinkLeslie medium (CENTRO PANAMERICANO DE ZOONOSIS, 1985). The readings were performed after 45 days of incubation at $36^{\circ} \mathrm{C}$. The dilution chosen for the bacterial count contained between 10 and 150 colonies, and the result was expressed in $\log \mathrm{CFU} \mathrm{mL} \mathrm{m}^{-1}$.

\section{Results and Discussion}

The fat content of the milk cream ranged between $34 \%$ and $37 \%$, and this product was classified as medium-fat milk cream (BRASIL, 1996). The average heating time was $1 \mathrm{~min}$ and $41 \mathrm{~s}$ for the product to reach a temperature of $75^{\circ} \mathrm{C}, 2 \mathrm{~min}$ and $13 \mathrm{~s}$ to reach $80^{\circ} \mathrm{C}, 2 \mathrm{~min}$ and $46 \mathrm{~s}$ to reach $85^{\circ} \mathrm{C}$, and $3 \mathrm{~min}$ and $51 \mathrm{~s}$ to reach $90^{\circ} \mathrm{C}$. The IL was 8.0 $\log \mathrm{CFU} \mathrm{mL} \mathrm{m}^{-1}$ and the bacterial load ranged between 7.8 and $8.3 \log \mathrm{CFU} \mathrm{mL} \mathrm{m}^{-1}$. The load of M. bovis decreased as a function of length and temperature of the treatment. The most effective temperature for the reduction of the bacterial count was $90^{\circ} \mathrm{C}$, which led to a complete inactivation of the inoculum in some replicates; more specifically, counts were lower than $100 \mathrm{CFU} \mathrm{mL}^{-1}$. Figure 1 shows the decay of $M$. bovis for each thermal treatment.

Figure 1. Decay of the population of Mycobacterium bovis (spoligotype SB1141, $\log \mathrm{CFU}_{\mathrm{mL}}^{-1}$ ) in milk cream as a function of time and temperature of the treatment in a water bath.

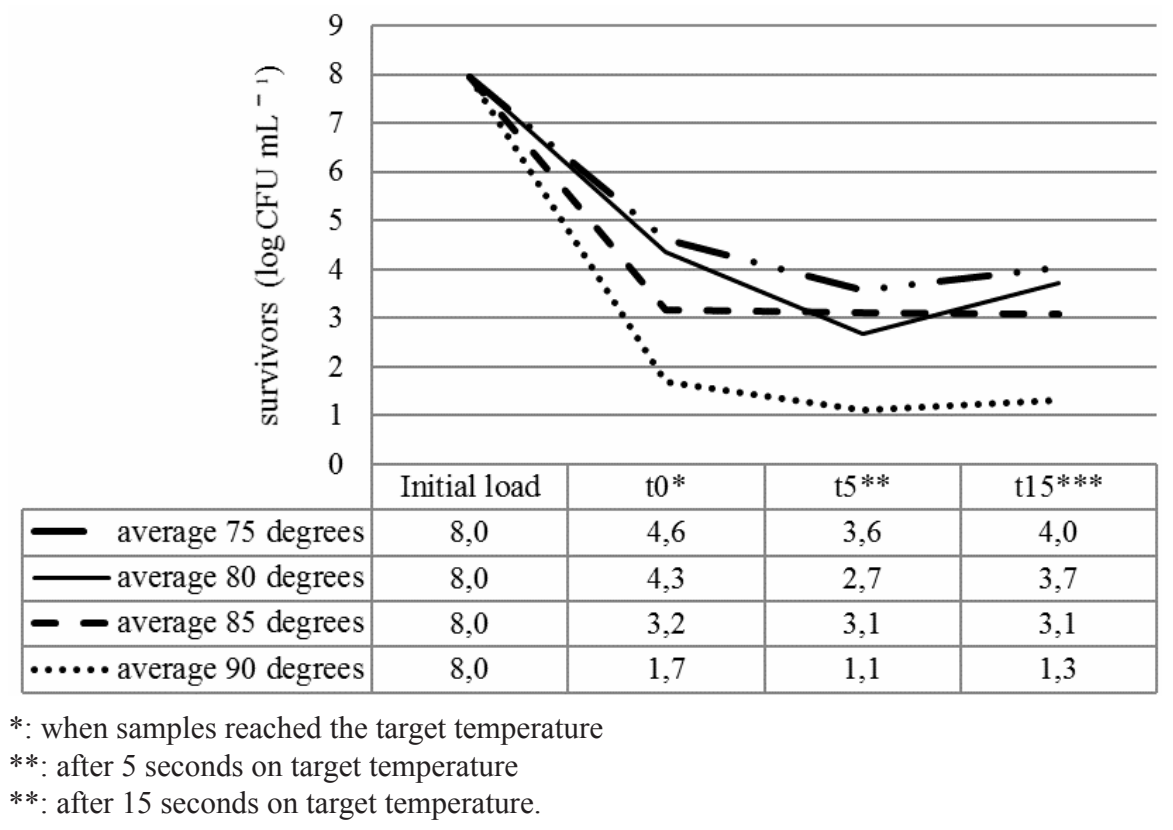


Ribeiro et al. (2016a) evaluated the survival of the same spoligotype (SB1141) at $72^{\circ} \mathrm{C}$ for $20 \mathrm{~s}$ in UHT whole milk and the results obtained were similar to the ones we obtained for the treatment combination of $75^{\circ} \mathrm{C}$ and $15 \mathrm{~s}$. This finding is of particular interest because milk cream contains approximately 10 times the fat content that is usually found in UHT whole milk. In addition, the heating time needed for the sample to reach the target temperature was similar in both studies [1 $\mathrm{min}$ $45 \mathrm{sec}$ (WB at $85^{\circ} \mathrm{C}$ ), Ribeiro et al. (2016a); $1 \mathrm{~min}$ and $41 \mathrm{sec}\left(\mathrm{WB}\right.$ at $\left.95^{\circ} \mathrm{C}\right)$, present study]. This result indicates that the penetration of heat in milk cream is similar to that in whole milk and suggests that the effect of this process is similar in both substrates.

The heating step was the most efficient in inactivating the microorganism (Figure 1), which is consistent with the result obtained by Ribeiro et al. (2016a). Grant et al. (1996) evaluated the resistance of Mycobacterium paratuberculosis under conditions of slow pasteurization and observed a significant decrease in bacterial load in the first third of the process followed by a slight reduction in the bacterial load. The results obtained by Sung and Collins (1998) suggest that mycobacteria can adjust to different temperatures by producing heat shock proteins or other molecules able to protect them against the deleterious effects of heat during the later phase of temperature maintenance. The authors also found that, when $M$. paratuberculosis was inoculated into an unheated substrate, a reduction of $1 \log \mathrm{CFU} \mathrm{mL} \mathrm{mL}^{-1}$ was observed after 90 $\mathrm{s}$ of incubation at $71^{\circ} \mathrm{C}$; however, when the same substrate previously heated to $71^{\circ} \mathrm{C}$ was inoculated with $M$. paratuberculosis, a reduction of $6 \log \mathrm{CFU}$ $\mathrm{mL}^{-1}$ was observed after the same time.

We found that the treatment at $90^{\circ} \mathrm{C}$ was the most effective and resulted in a decrease in the number of $M$. bovis cells of up to $6.9 \log \mathrm{CFU}$ $\mathrm{mL}^{-1}$ in milk cream; in addition, although not as effective, the treatment at $75^{\circ} \mathrm{C}$ significantly decreased the viability of $M$. bovis in milk cream (4 $\log$ CFU mL-1).
The similarity between the results of bacterial survival in whole milk and milk cream, together with the comparable heating times used for the two products, suggests that the fat content does not influence the lethal effect of the pasteurization process in the presence of the fat percentages tested.

It can be inferred that pasteurization at $75^{\circ} \mathrm{C}$ for $15 \mathrm{~s}$ has the same level of safety for milk cream and whole milk, with respect to contamination with M. bovis. However, considering the lipophilic character of $M$. bovis and the higher concentration of fat in milk cream, approximately 10-fold in this case, it is reasonable to assume that, in the natural pasteurization process of milk cream, the initial bacterial load would be 10 times higher than the one found in whole milk. After pasteurization, the final bacterial load in milk cream would also be 10 times higher than the one in pasteurized milk. In this scenario, assuming an initial load of $10^{4} \mathrm{CFU}$ $\mathrm{mL}^{-1}$ in whole milk, which constitutes the maximum natural contamination of milk (BALL, 1943), it can be assumed that the initial load in milk cream would be approximately $10^{5} \mathrm{CFU} \mathrm{mL}^{-1}$. For milk cream subjected to pasteurization at $75^{\circ} \mathrm{C}$ for $15 \mathrm{~s}$, the final load would be $10 \mathrm{CFU} \mathrm{mL}^{-1}$. However, it is also reasonable to assume that the initial load of $M$. bovis in milk cream is lower than the one obtained in the simulation, considering its likely dilution with uncontaminated milk.

It is difficult to determine the actual significance of these findings for public health, because the initial bacterial load in the milk mixture and the oral infectious dose of $M$. bovis, among other factors, remain unknown (SINHA, 1994); however, we suggest that pasteurization temperatures higher than those approved for the pasteurization of whole milk should be used for milk cream, unless thermal inactivation is performed before the separation of the cream. 


\section{Acknowledgments}

The authors acknowledge the financial support from $\mathrm{CNPq}$ and FAPESP

\section{References}

BAHIENSE, L.; ÁVILA, L. N. de; BAVIA, M. E.; AMAKU, M.; DIAS, R. A.; GRISI-FILHO, J. H. H.; FERREIRA, F.; TELLES, E. O.; GONÇALVES, V. S. P.; HEINEMANN, M. B.; FERREIRA NETO, J. S. Prevalence and risk factors for bovine tuberculosis in the State of Bahia, Brazil. Semina: Ciências Agrárias, Londrina, v. 37, n. 5, p. 3549-3560, 2016. Suplemento 2.

BALL, C. O. Short time pasteurization of milk. Industrial Engineering Chemistry, v. 35, p. 71-84, 1943.

BARBIERI, J. M.; OLIVEIRA, L. F.; DORNELES, E. M. S.; MOTA, A. L. A. A.; GONÇALVES, V. S. P.; MALUF, P. P.; FERREIRA NETO, J. S.; FERREIRA, F.; DIAS, R. A.; TELLES, E. O.; GRISI-FILHO, J. H. H.; HEINEMANN, M. B.; AMAKU, M.; LAGE, A. P. Epidemiological status of bovine tuberculosis in the state of Minas Gerais, Brazil, 2013. Semina: Ciências Agrárias, Londrina, v. 37, n. 5, p. 3531-3548, 2016. Suplemento 2.

BRASIL. Ministério da Agricultura, Pecuária e Abastecimento. Instrução Normativa n.68, de 12 dez. 2006. Oficializa os métodos analíticos oficiais físicoquímicos, para controle de leite e produtos lácteos, em conformidade com o anexo desta instrução normativa, determinando que sejam utilizados nos laboratórios nacionais agropecuários. Brasília: MAPA, 2006. Disponível em: <http://extranet.agricultura.gov.br/ sislegis-consulta/consultarLegislacao.do?operacao $=$ visu alizar\&id=17472>. Acesso em: 10 out. 2016.

Portaria 146, de 7 de março de 1996: anexo IV. Regulamento técnico de Identidade e qualidade de creme de leite. Brasília: MAPA, 1996. Disponível em: <http://extranet.agricultura.gov.br/ sislegis-consulta/consultarLegislacao.do?operacao $=$ visu alizar\&id=1218>. Acesso em: 10 out. 2016.

BUSSATA, C.; VALDRUGA, E.; CANSIA, R. L. Ocorrência de Bacillus sporothermodurans em leite UAT integral e desnatado. Ciência e Tecnologia de Alimentos, Campinas, v. 25, n. 3, p. 408-411, 2005.

CENTRO PANAMERICANO DE ZOONOSIS SIGLA. Manual de normas y procedimentos técnicos para a bacteriologia de la tuberculosis. Buenos Aires: OPAS/OMS, 1985, 25 p. (Nota técnica, 27).
CHABRA, A. T.; CARTER, W. H.; LINTON, R. T.; COUSIN, M. A. A predictive model to determine the effects of $\mathrm{pH}$, milk fat, and temperature on thermal inactivation of Listeria monocytogenes. Journal of Food Protection, Des Moines, v. 62, n. 10, p. 1143-1149, 1999.

DIAS, R. A.; STANOJLOVIC, F. M. U.; BELCHIOR, A. P. C.; FERREIRA, R. S.; GONÇALVES, R. C.; AGUIAR, R. S. C. B.; SOUSA, P. R.; SANTOS, A. M. A.; AMAKU, M.; FERREIRA, F.; TELLES, E. O.; GRISI-FILHO, J. H. H.; GONÇALVES, V. S. P.; HEINEMANN, M. B.; FERREIRA NETO, J. S. Prevalence and risk factors for bovine tuberculosis in the state of São Paulo, Brazil. Semina: Ciências Agrárias, Londrina, v. 37, n. 5, p. 3673-3684, 2016. Suplemento 2.

DONNELLY, C. W.; BRIGGS, E. H. Psychotropic growth and thermal inactivation of Listeria monocytogenes as a function of milk composition. Journal of Food Protection, Des Moines, v. 49, n. 12, p. 994-998, 1986.

LANDGRAF, M. Controle do desenvolvimento microbiano nos Alimentos. In: FRANCO, B. D. G. M.; LANDGRAF, M. Microbiologia dos alimentos. São Paulo: Atheneu, 1996. p. 109-148.

GALVIS, J. O. A.; GRISI-FILHO, J. H. H; COSTA, D.; SAID, A. L. P. R.; AMAKU, M.; DIAS, R. A.; FERREIRA, F.; GONÇALVES, V. S. P.; HEINEMANN, M. B.; TELLES, E. O.; FERREIRA NETO, J. S. Epidemiologic characterization of bovine tuberculosis in the state of Espírito Santo, Brazil. Semina: Ciências Agrárias, Londrina, v. 37, n. 5, p. 3567-3578, 2016. Suplemento 2.

GRANT, I. R; BALL, H. J.; NEILL, S. D.; ROWE, M. $\mathrm{T}$. Inactivation of Mycobacterium paratiberculosis in cows 'milk at pasteurization temperatures. Applied and Environmental Microbiology, Washington, v. 62, n. 2, p. 631-636, 1996.

GUEDES, I. B.; BOTTENE, I. F. N.; MONTEIRO, L. A. R. C.; LEAL FILHO, J. M.; HEINEMANN, M. B.; AMAKU, M.; GRISI-FILHO, J. H. H.; DIAS, R. A.; FERREIRA, F.; TELLES, E. O.; GONÇALVES, V. S. P.; FERREIRA NETO, J. S. Prevalence and risk factors for bovine tuberculosis in the state of Mato Grosso do Sul, Brazil. Semina: Ciências Agrárias, Londrina, v. 37, n. 5, p. 3579-3588, 2016. Suplemento 2.

LIMA, P. B.; NASCIMENTO, D. L.; ALMEIDA, E. C.; PONTUAL, K. A. Q.; AMAKU, M.; DIAS, R. A.; FERREIRA, F.; GONÇALVES, V. S. P.; TELLES, E. O.; GRISI-FILHO, J. H. H.; HEINEMANN, M. B.; SILVA, J. C. R.; FERREIRA NETO, J. S. Epidemiological situation of bovine tuberculosis in the state of Pernambuco, Brazil. Semina: Ciências Agrárias, Londrina, v. 37, n. 5, p. 3601-3610, 2016. Suplemento 2. 
MACDONALD, F.; SUTHERLAND, A. D. Effect of heat treatment on Listeria monocytogenes and Gram negative bacteria in sheep, cow and goat milk. Journal of Applied Bacteriology, Hoboken, v. 75, n. 4, p. 336-343, 1993.

MOLIN, N.; SNYGG, B. G. Effect of lipid materials on heat resistance of bacterial spores. Journal of Applied Microbiology, Hoboken, v. 15, n. 6, p. 1422-1426, 1967.

NÉSPOLI, J. M. B.; NEGREIROS, R. L.; AMAKU, M.; DIAS, R. A.; FERREIRA, F.; TELLES, E. O.; HEINEMANN, M. B.; GRISI-FILHO, J. H. H.; GONÇALVES, V. S. P.; FERREIRA NETO, J. S. Epidemiological situation of bovine tuberculosis in the state of Mato Grosso, Brazil. Semina: Ciências Agrárias, Londrina, v. 37, n. 5, p. 3589-3600, 2016. Suplemento 2.

ORDÓÑES PEREDA, J. A.; RODRÍGUEZ, M. I. C.; ÁLVARES, L. F.; SANZ, M. L.G.; MINGUILLÓN, G. D. G. F.; PERALES, L. H.; CORTECERO, M. D. S. Tecnologia de alimentos 2. Porto Alegre: Artmed, 2005. 279 p.

QUEIROZ, M. R.; GROFF, A. C. M.; SILVA, N. S.; GRISI-FILHO, J. H. H.; AMAKU, M.; DIAS, R. A.; TELLES, E. O.; HEINEMANN, M. B.; FERREIRA NETO, J. S.; GONÇALVES, V. S. P.; FERREIRA, F. Epidemiological status of bovine tuberculosis in the state of Rio Grande do Sul, Brazil. Semina: Ciências Agrárias, Londrina, v. 37, n. 5, p. 3647-3658, 2016. Suplemento 2.

RIBEIRO, L.; NARCISO, M., R. T.; FELIPE, T. H.; STARIKOFF, K. R.; SOUZA, G. O.; NETO, J. S. F.; FERREIRA, F.; AMAKU, M.; DIAS, R. A.; GONÇALVES, V. S. P.; HEINEMANN, M. B.; TELLES, E. O. Decay of Mycobacterium bovis in whole milk submitted to pasteurization parameters. Semina: Ciências Agrárias, Londrina, v. 37, n. 5, p. 3727-3736, 2016a. Suplemento 2.

RIBEIRO, L. A.; GONÇALVES, V. S. P.; FRANCISCO, P. F. C.; MOTA, A. L. A. A.; NASCIMENTO, G. T.; LICURGO, J. B.; FERREIRA, F.; GRISI-FILHO, J. H. H.; FERREIRA NETO, J. S.; AMAKU, M.; DIAS, R. A.; TELLES, E. O.; HEINEMANN, M. B.; BORGES, J. R. J. Epidemiological status of bovine tuberculosis in the Federal District of Brazil. Semina: Ciências Agrárias, Londrina, v. 37, n. 5, p. 3561-3566, 2016. Suplemento 2.
ROCHA, W.V.; JAYME, V. S.; MOTA, A. L. A. A.; BRITO, W. M. E. D.; PIRES, G. R. C; GRISI-FILHO, J. H. H.; DIAS, R. A.; AMAKU, M.; TELLES, E. O.; HEINEMANN, M. B.; FERREIRA, F.; FERREIRA NETO, J. S.; GONÇALVES, V. S. P. Prevalence and herd-level risk factors of bovine tuberculosis in the State of Goiás, Brazil. Semina: Ciências Agrárias, Londrina, v. 37, n. 5, p. 3625-3628, 2016. Suplemento 2.

RODRIGUEZ, C. A. R.; ZUMARRAGA, M. J.; OLIVEIRA, E. M. D.; CATALDI, A. A.; ROMANO, M. I.; OTTO, H. H.; BONAFÉ, V. L.; FERREIRANETO, J. S. Caracterização molecular de isolados de Mycobacterium bovis do Estado São Paulo, Brasil, utilizando a técnica de Spoligotyping. Arquivos do Instituto Biológico, São Paulo, v. 71, n. 3, p. 277-282, 2004.

SILVA, M. C. P.; GONÇALVES, V. S. P.; MOTA, A. L. A. A.; KOLODA, M.; FERREIRA NETO, J. S.; GRISIFILHO, J. H. H.; DIAS, R. A.; AMAKU, M.; TELLES, E. O.; FERREIRA, F.; HEINEMANN, M. B.; ALFIERI, A. A.; MULLER, E. E. Prevalence and herd-level risk factors for bovine tuberculosis in the state of Paraná, Brazil. Semina: Ciências Agrárias, Londrina, v. 37, n. 5, p. 3611-3624, 2016. Suplemento 2.

SINHA, R. N. Mycobacterium bovis (Chapter 11). In: International Dairy Federation, IDF/FIL. The significance of pathogenic microorganisms in raw milk. Bruxels: International Dairy Federation, IDF/FIL, 1994. p. 141-166.

SUNG, N.; COLLINS, M. T. Thermal tolerance of Mycobacterium paratuberculosis. Applied and Environmental Microbiology, Washington, v. 64, n. 3, p. 999-1005, 1998.

VELOSO, F. P.; BAUMGARTEN, K. D.; MOTA, A. L. A. A.; FERREIRA, F.; FERREIRA NETO, J. S.; GRISI-FILHO, J. H. H.; DIAS, R. A.; AMAKU, M.; TELLES, E. O.; HEINEMANN, M. B.; GONÇALVES, V. S. P. Prevalence and herd-level risk factors of bovine tuberculosis in the State of Santa Catarina, Brazil. Semina: Ciências Agrárias, Londrina, v. 37, n. 5, p. 3659-3672, 2016. Suplemento 2.

VENDRAME, F. B.; AMAKU, M.; FERREIRA, F.; TELLES, E. O.; GRISI-FILHO, J. H. H.; GONÇALVES, V. S. P.; HEINEMANN, M. B.; FERREIRA NETO, J. S.; DIAS, R. A. Epidemiologic characterization of bovine tuberculosis in the State of Rondônia, Brazil. Semina: Ciências Agrárias, Londrina, v. 37, n. 5, p. 3639-3646, 2016. Suplemento 2. 